\title{
Some features of crustacean cultivation aquabiotechnology on the waters of energy facilities
}

\author{
Marina $\mathrm{Kalaida}^{1}$, Madina $\mathrm{Khamitova}^{1}$, and Svetlana Borisova ${ }^{1}$ \\ ${ }^{1}$ FSBEI HE "Kazan State Power Engineering University", Department of "Aquatic Bioresources and Aquaculture", Kazan, Russia
}

\begin{abstract}
The data on the state of the crayfish population on the territory of the Middle Volga before its regulation and after the formation of reservoirs are presented. Three stages in the state of development of aquabiotechnology of the crustaceans cultivation in the Middle Volga region have been identified. The first stage is before regulation of the Volga river. The second stage is pasture aquaculture in reservoirs with works on the targeted improvement of aquatic ecosystems. It is shown that the size-weight and ecologicalbiological characteristics of long-clawed crayfish before the regulation of the river and after the formation of the Kuibyshev reservoir are similar. The third stage is highlighted in connection with the expansion of biotechnologies for growing thermophilic crayfish in recirculating aquaculture systems. At the present stage, in the Kuibyshev and Nizhnekamsk reservoirs, there are narrow-clawed (Pontastacus leptodactylus Esch.) and wide-clawed crayfish (Astacus astacus L.). The catches contain crayfish of three ages: two-yearolds - about $100 \mathrm{~mm}$, three-year-olds - about $150 \mathrm{~mm}$, four-year-olds - about $170 \mathrm{~mm}$ long. The equation for the dependence of body weight on the zoological length of narrow-clawed crayfish in the Kuibyshev reservoir: $y=0.67 x+81.3$. The cultivation of the red claw crayfish Cherax quadricarinatus (VonMartens, 1868) on the warm waters of energy facilities can become an important element of aquaculture for the production of elite gourmet products. The equation for the dependence of body weight on the zoological length of red claw crayfish in a recirculating aquaculture system: $y=1.1 x+57.3$. The development of aquatic biotechnologies makes it possible to use natural crayfish populations for the creation of crayfish farms and pasture aquaculture on the basis of reservoir waters, and the use of warm waters makes it possible to grow new aquaculture objects for the industrial crayfish cultivation all year round. At the same time, natural ecosystems are not disturbed, and the rate of growth of marketable products under controlled production conditions allows not only to increase the volume of aquaculture products, but also to reduce the pressure of catch of crayfish from natural ecosystems.
\end{abstract}

\section{Introduction}

Historically, the technological and economic development of the Middle Volga region is closely related to the development of energy. 100 years have passed since the adoption of the GOELRO plan, when a decision was made to develop the country's industrial potential through the development of electrification. This event subsequently changed the entire appearance of the Volga River and was reflected not only in the complex of physicochemical characteristics of the water basin, but also in the appearance of the biota.

Consecutive changes in aquatic ecosystems as a result of hydro construction, an increase in anthropogenic load, improvement of environmental policy led to the development of aquaculture as a new stage in the interaction of aquatic ecosystems and humans.

Today, it is already possible to trace changes that are significant from an ecological point of view and outline tasks for preserving the quality of waters and aquatic biological resources $[1,2,3]$. Successful implementation of the planned actions with environmental consequences requires the application of the principles of a systematic approach to the management of aquatic biological resources [4].

Crustaceans are indicative and valuable food organisms in aquatic ecosystems. The purpose of our study is to show the diversity of crayfish cultivation possibilities in the conditions of the modern Middle Volga region.

\section{Material and research technique}

In the course of the work, the analysis of the results of our own research and literature data on the ecology and biology of commercially valuable crayfish, statistical data on the catch of crustaceans has been done. Traditional methods were used to analyze the population structure and biological characteristics of crayfish. The materials on the river crayfish of the Kuibyshev and Nizhnekamsk reservoirs, the Kama, Izh, Belaya, Prost rivers, sampled in the spring and autumn of 2017 and 
2018 were analyzed and summarized. At each investigated reservoir, at least 200 individuals of different sex and age were analyzed. To analyze the characteristics of the growth and reproduction of crayfish in industrial conditions, we used long-clawed and red-clawed crayfish contained in a recirculating aquaculture system of the Department of Water Bioresources and Aquaculture of the FSBEI HE KSPEU from 2017 to the present.

\section{Results and discussion}

Several stages can be distinguished in the development of crayfish farming on the territory of the Middle Volga region.

The first stage is the period before the implementation of the GOELRO plan, when a decision was made to develop the country's industrial potential through the development of electrification and a working hypothesis was developed for a comprehensive scheme for using the Volga for energy and transport purposes, a whole series of questions immediately arose on changing the ecosystem of the main water artery of the center of Russia. To solve environmental problems in the 30 s of the last century, work was carried out to study the floodplain Volga lakes as future sources of settlement of the reservoir.

During this period, studies of crayfish are carried out in the Middle Volga region [5]. It was noted that at the beginning of life, females and males of crayfish grow at the same rate, and then during puberty, the growth rate of females decreases. The ratio in catches of females to males was 30\%: 70\% in summer catches and in autumn 44\%: 56\%. At that time, crayfish yearlings were about 4 $\mathrm{cm}$ long, two-year-old females and males averaged 10.5 $\mathrm{cm}$, three-year males $14.5 \mathrm{~cm}$, and females $13.5 \mathrm{~cm}$. The four-year-olds were about $17.5 \mathrm{~cm}$ in size and were all males. The growth rate of crayfish in the floodplain lakes of the Volga River was higher than in small rivers.

The dependence of the mass of long- clawed crayfish on length under the conditions of the Volga River from net catches in the 30 s of the 20th century is shown in Fig. 1 to [5].

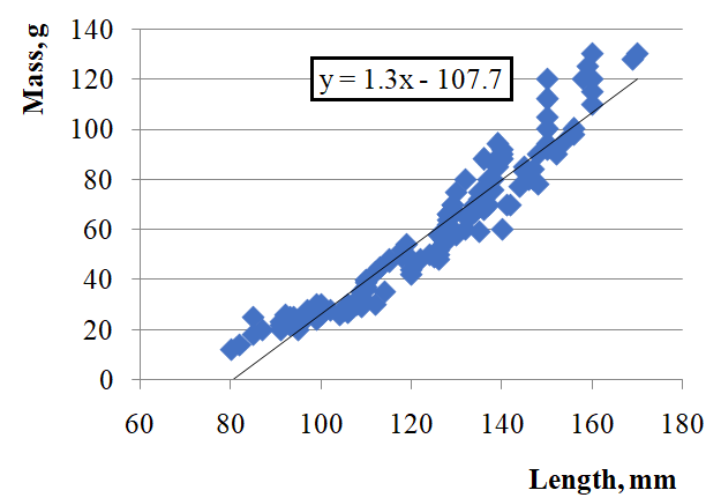

Fig. 1. Dependence of body weight on the length of crayfish from net catches before regulation of the Volga River.
The equation for the dependence of body weight on the length of narrow-clawed crayfish in the Volga River before its regulation: $y=1.3 x-107.7$.

Sexual maturity in female crayfish began in the third year of life and is associated with the growth rate. As a result of the conducted fishery studies of aquatic organisms before the regulation of the Volga River, the commercial length of narrow-clawed crayfish was proposed, when harvesting in small rivers no less than 8.0-8.5 cm, for productive lakes - more than 10.5-12.5 $\mathrm{cm}$ [5]. Crayfish older than 4 years were not found in small rivers and floodplain lakes.

In studies of crayfish in Volga River it was noted that in 1898-1900. in the waters of the Middle Volga, including the rivers Ik, Sviyaga, Zai, Cheremshan and Bezdna, the epidemic of the crayfish plague [5] almost completely destroyed the population of broad-clawed crayfish in the region, after which, by 1935, the population of crayfish began to recover at the expense of narrow-clawed crayfish, which were found locally in commercial quantities.

According to historical references, narrow-clawed crayfish have been harvested mainly in the lower part of the Volga basin and in the Caspian Sea since the 1880s [6]. In 1910-1974, the crayfish fishery on the eastern coast of the Caspian Sea resulted in annual catches of about 50 tons on average, ranging from 0.96 tons (1998) to 119 tons $(1962)[6,7]$.

Thus, commercial fishing for freshwater crayfish during this period was based on narrow-clawed crayfish, while broad- clawed crayfish was practically absent.

For the stage of formation of schemes of solutions for the ecological component of the problem of the "Big Volga" and the emergence of reservoirs, an important direction of work was the directed formation of hydrobiocenoses. During this period, the foundations for the acclimatization of aquatic organisms were laid, when in 1940-1941 V.I. Zhadin [8], in connection with the Volga hydroelectric construction, suggested that the fauna of the created reservoirs was not saturated and that it was possible to enrich it by acclimatizing invertebrates from other water bodies. F.D. Mordukhai-Boltovskoy (1947) emphasized that the Caspian fauna inhabiting the Azov-Black Sea basin can be considered as a rich fund for the acclimatization of aquatic organisms in many inland water bodies. For the introduction into the reservoirs, 52 species of invertebrates were used. Zoogeographically, the overwhelming majority of the introduced invertebrates (over 70\%) belong to the autochthonous fauna of the Caspian type [9].

The most represented group of crayfish in the Middle Volga region is narrow-clawed crayfish (Pontastacus leptodactylus Esch.). Narrow-clawed crayfish spread from the Ponto-Caspian basin by zoological waves [10, $11,12]$, pushing wide-clawed crayfish to the north and northwest.

Work was also carried out on the acclimatization of crayfish: striped crayfish Orconectes limosus (Rafinesque, 1817) and signal crayfish Pacifastacus leniusculus (Dana, 1852) were introduced from America. In places of distribution, striped crayfish is not protected, its fishing is allowed throughout the year due to its 
relatively low market value: the meat yield is about 13\% $[13,14]$. Its rapid growth, high fertility, ability to survive well under conditions of high concentrations of organic matter and relatively low oxygen content lead to its dominance and displacement of native species.

The signal crayfish Pacifastacus leniusculus (Dana, 1852) lives in the same biocenoses in which the wideclawed crayfish was found, and differs from it in a higher growth rate, greater fertility, and earlier sexual maturation. Signal crayfish is resistant to the disease of crayfish plague, but it can be a carrier and in nature it displaces broad-fingered crayfish [15].

Broad-fingered crayfish (Astacus Astacus L.) live mainly in the North-West of Russia, in the water bodies of the Baltic Sea basin.

The second stage in the development of aquabiotechnologies in the field of crayfish farming can be distinguished after the organization of the cascade of the Volga reservoirs and the formation of hydrobiocenoses.

A characteristic direction of work for the time was the identification of factors affecting the dynamics of the number of crayfish for the development of measures to increase their stocks and preserve the population [12, 13]. During the period of the establishment of the Kuibyshev reservoir in the Republic of Tatarstan, crayfish were not considered as significant objects of pasture aquaculture.

The creation of reservoirs and the limitation of catches in the early stages of their existence contributed to an increase in the stocks of crayfish, primarily narrowclawed crayfish.

By the end of the 20th century, the stocks of crayfish and the total allowable catches according to [16] in the Volga reservoirs are shown in Fig. 2.

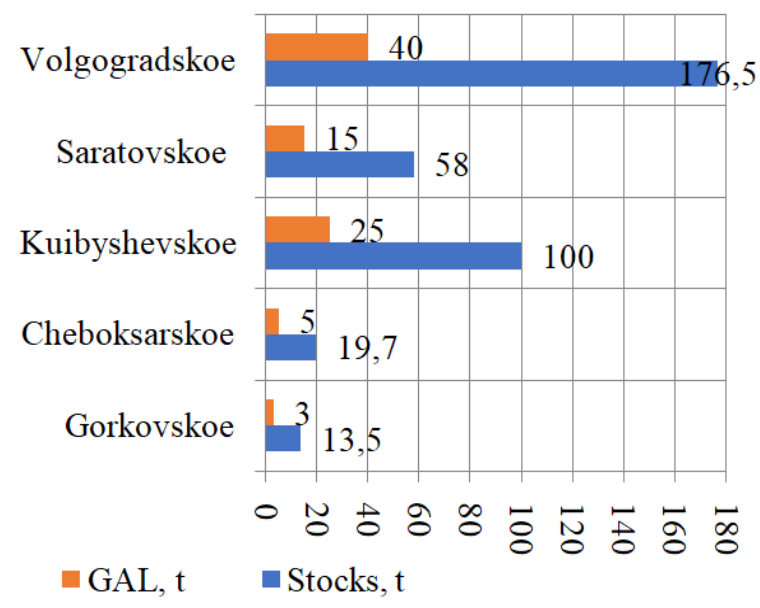

Fig. 2. Stocks and total allowable catches (TAC) of crayfish in the reservoirs of the Volga River according to [16].

In the 1980s, the export of crayfish from Russia practically ceased.

In the Kuibyshev reservoir, no work was carried out on the introduction of American crayfish species. By the 1990s, the idea of invasive species was formed and American signal and striped crayfish were included in the lists of dangerous invasive animals. In this regard, since the end of the 20th century, their introduction has not been carried out, measures have been taken to limit their spread [17], the situation is similar in Russia: the introduction of signal crayfish has not been recommended since 1990 [13].

At the same time, during this period, the activity on the study of the biology of crayfish and the creation of biotechnologies for the artificial production of juveniles, their growth to viable stages for release into natural water bodies, is expanding. By the end of the 20th century, biotechnologies for the artificial production of juveniles of broad-clawed, narrow-clawed and signal crayfish were developed [13]. The particular significance of these works was associated with the inclusion of the broad-clawed crayfish in the Red Books of a number of regions, for example, the Republic of Tatarstan.

Research of crayfish of the Kuibyshev and Nizhnekamsk reservoirs and the Kama, Izh, Belaya, Prost rivers, carried out by us in 2017 and 2018, revealed a number of their ecological and biological characteristics $[19,20]$ in the reservoirs of the Middle Volga region.

Studies have shown that both types of crayfish are represented in the Middle Volga region: broad-clawed or noble crayfish (Astacus astacus L.) and narrow-clawed crayfish (Pontastacus leptodactylus Esch.) (Fig. 3), and also crayfish with blue color were found.

In the zone of the Kuibyshev reservoir, the ratio of narrow-clawed to broad-clawed crayfish was 1:0 in some areas (near the city of Bulgar), in the area of the Spassky GPKZ - 3:2, and in the zone of the Nizhnekamsk reservoir - 1:1. In this case, females of narrow-clawed crayfish made up $27.8 \%$, and females of wide-clawed crayfish - $20 \%$ of the total number of crayfish of these species. Crayfish were found in catches at different depths: from the beginning of February - from 2 to $3 \mathrm{~m}$, at the end of February they were not caught at any depths, in March they were caught at depths of more than $3 \mathrm{~m}$ and from mid-March - up to $6 \mathrm{~m}$.

In the Volzhsko-Kamsky reach in February, specimens with a maximum mass of crayfish up to $60 \mathrm{~g}$ with a maximum zoological body length from the rostrum to the end of the abdomen of about $130 \mathrm{~mm}$ were encountered. In March, individuals up to $100 \mathrm{~g}$ with a body length of $170 \mathrm{~mm}$ were encountered in the same areas.
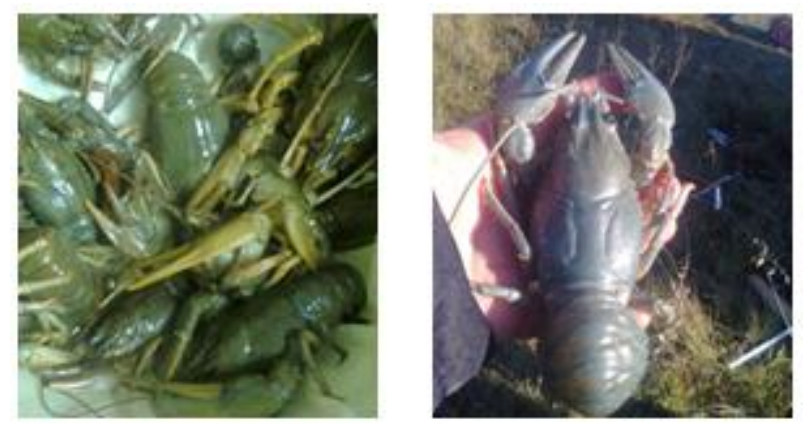

Fig. 3. River crayfish from the catches of the Volga, Kama and Belaya rivers in 2017. 
The size and weight characteristics of females and males of narrow-clawed crayfish in the Kuibyshev reservoir are shown in Fig. 4.

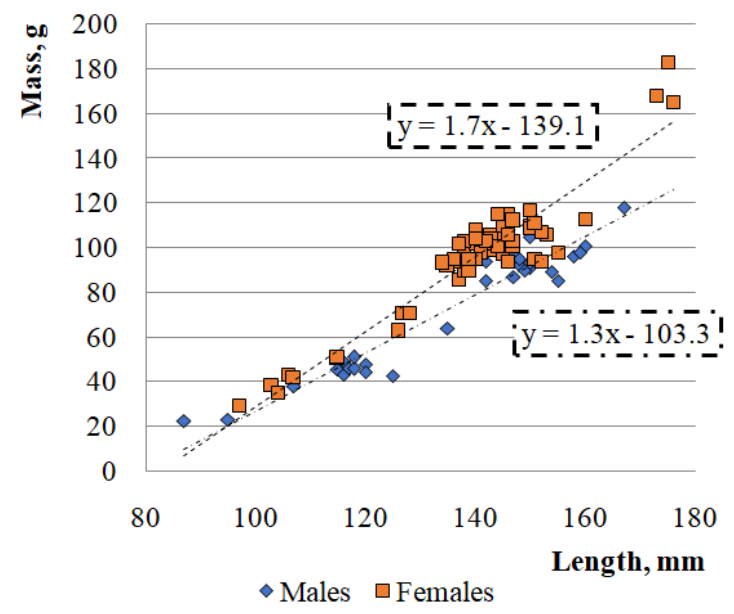

Fig. 4. Comparison of body weight and length in females and males of narrow-clawed crayfish in the Volzhsko-Kamsky reach of the Kuibyshev reservoir.

Most of the crayfish is represented by males with size characteristics of about $150 \mathrm{~mm}$ in length and a mass of about $100 \mathrm{~g}$. Males have a larger mass in comparison with females - due to the mass of claws.

The study of the size-age structure of crayfish showed that the catches contain crayfish of three ages: two-year-olds were about $100 \mathrm{~mm}$ long, three-year-olds formed the basis of the caught individuals and were about $150 \mathrm{~mm}$ long, some individuals of males - about $170 \mathrm{~mm}$ long were four-year-olds, while their weight exceeded $160 \mathrm{~g}$.

Sexual maturity in females of long-toed crayfish from the Volga River, prior to its regulation, began in the third year of life, with a zoological length of 12 to 13.5 $\mathrm{cm}$ [5]. When organizing the fishery, it was proposed to use the fishing length for crayfish from small rivers no less than $8.0-8.5 \mathrm{~cm}$, for productive lakes - more than $10.5-12.5 \mathrm{~cm}$. Crayfish older than 4 years did not occur [5].

In our materials females with eggs were encountered from May 10 to 20 and they had a zoological length of 12 to $15.5 \mathrm{~cm}$.

The analysis of mass accumulation by crayfish depending on the zoological and commercial length is shown in Fig. 5. With the minimum commercial size of crayfish harvested $-10 \mathrm{~cm}$ in accordance with the fishing rules for the Volga-Caspian fishery basin, all crayfish weigh more than $40 \mathrm{~g}$. Crayfish of high commercial quality - more than $100 \mathrm{~g}$ - had a fishing length of 130 $\mathrm{mm}$ with a zoological length of $145 \mathrm{~mm}$ (Fig. 5).

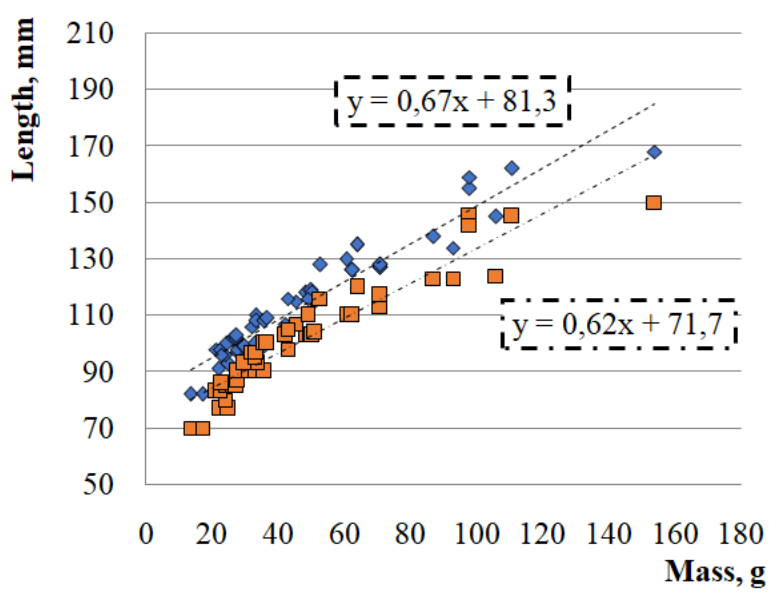

Fig. 5. Dependence of body weight on the absolute and commercial length in narrow-clawed crayfish in the VolzhskoKamsky reach of the Kuibyshev reservoir.

An analysis of the size-age structure revealed that the catches contained crayfish of three ages: two-year-olds were about $100 \mathrm{~mm}$ long, three-year-olds formed the basis of the caught individuals and had a length of about $150 \mathrm{~mm}$, single males - about 170 were four-year-olds, while their weight exceeded $160 \mathrm{~g}$.

The third stage in the development of aquabiotechnologies in the field of crayfish cultivation can be distinguished in connection with the expansion of biotechnologies for growing thermophilic crayfish on the basis of recirculating aquaculture systems and on warm waters of energy facilities.

This stage naturally develops on the territory of the Middle Volga region the worldwide tendencies for an increase in the production of crustaceans in aquaculture [21].

The cultivation of the Australian red-claw or red-toed crayfish Cherax quadricarinatus (Von Martens, 1868), as an environmentally friendly product, in warm waters can become an important element of aquaculture for the production of elite gourmet products. Australian red claw crayfish in comparison with crayfish of the Middle Volga (narrow-clawed crayfish, wide-clawed crayfish) is characterized by a high growth rate, the ability to grow in high temperatures [22]. Experimental studies on the cultivation and reproduction of red claw crayfish carried by us in the recirculating aquaculture system at the Department of Aquatic Bioresources and Aquaculture of the Federal State Budgetary Educational Institution of Higher Education "KSPEU" revealed higher growth rates (Fig. 6) in red claw crayfish compared to narrowclawed. Narrow-clawed crayfish reach commercial sizes by the age of three, red-clawed crayfish by the age of $1+$.

The equation for the dependence of body weight on the zoological length of narrow-clawed crayfish in the Kuibyshev reservoir: $y=0.6734 x+81.316$.

The equation for the dependence of body weight on the zoological length of red claw crayfish in a recirculating aquaculture system: $y=1.1105 x+57.324$.

For the first time maturing females of red-clawed crayfish had a zoological length of 9 to $11 \mathrm{~cm}$ with a commercial length of 8.2 to $13 \mathrm{~cm}$. Their weight varied 
from 15 to $29 \mathrm{~g}$. The re-spawning female with eggs on the pleopods had a length of $151 \mathrm{~mm}$, a weight of $100 \mathrm{~g}$, and the width of her abdomen was $40 \mathrm{~mm}$. For other females, it varied from 22 to $25 \mathrm{~mm}$.

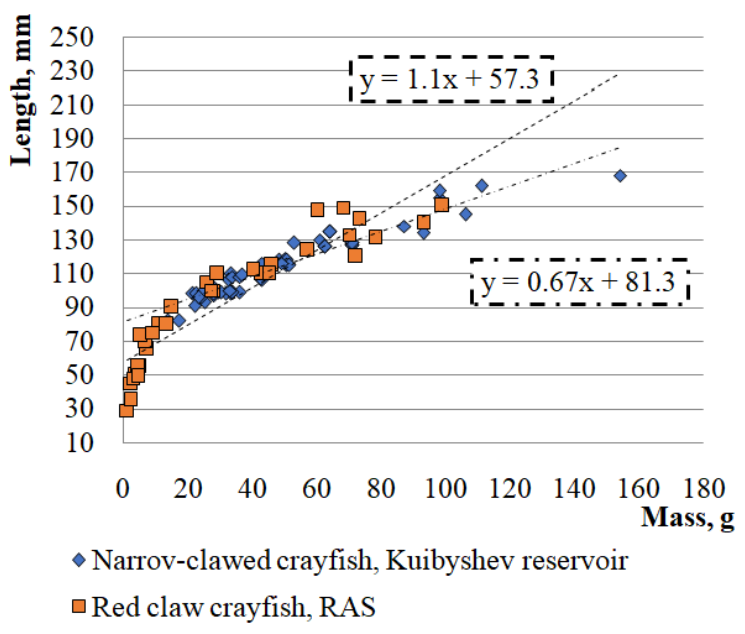

Fig. 6. Dependence of body weight on absolute length in narrow-clawed crayfish in the Kuibyshev reservoir and in redclaw crayfish from a recirculating aquaculture system.

Sexually mature red-clawed crayfish males had a zoological length of 10.8 to $14 \mathrm{~cm}$ with a commercial length of 10 to $12 \mathrm{~cm}$; abdominal width varied from 18 to $27 \mathrm{~mm}$. The weight of males ranged from 40 to $93 \mathrm{~g}$. The commercial weight of $70 \mathrm{~g}$ was reached by males of red claw crayfish with a zoological length of $12 \mathrm{~cm}$.

Considering that crayfish of commercial sizes in the Kuibyshev Reservoir are characterized by masses of more than $60 \mathrm{~g}$, it can be noted that red claw crayfish reach this mass with their zoological length of $12.5 \mathrm{~cm}$. Of particular importance is the fact that the inclusion of new promising cultivation objects does not affect the state of natural ecosystems.

\section{Conclusion}

Three stages in the state of development of aquabiotechnologies in the crayfish farming of the Middle Volga region have been identified. The first stage is before the regulation of the Volga River. It is characterized by the study of the morpho-biological and ecological characteristics of crayfish. The second stage after the formation of a cascade of reservoirs on the Volga River and the use of reservoirs for the tasks of pasture aquaculture with an effort to directionally improve aquatic ecosystems. This stage is characterized by the inclusion of American crayfish: signal crayfish (Pacifastacus leniusculus Dana, 1852) and striped crayfish (Orconectes limosus Rafinesque, 1817) into the ecosystems of domestic water bodies. American crayfish was not introduced into the Kuibyshev and Nizhnekamsk reservoirs. The third stage is highlighted in connection with the expansion of biotechnology for growing thermophilic crayfish on the basis of recirculating aquaculture systems. This stage is characterized by an increase in the share of crustaceans in the production of aquaculture objects against the background of a significant increase in world aquaculture production.

A study of crayfish in the Middle Volga region showed that at the present stage of the development of the ecosystem of the Kuibyshev and Nizhnekamsk reservoirs, there are narrow-clawed (Pontastacus leptodactylus Esch.) and wide-clawed crayfish (Astacus astacus L.). Most of crayfish in catches is represented by males with size characteristics of about $150 \mathrm{~mm}$ in length and weighing about $100 \mathrm{~g}$. The study of the sizeage structure of crayfish showed that the catches contain crayfish of three ages: two-year-olds - about $100 \mathrm{~mm}$, three-year-olds - about $150 \mathrm{~mm}$, which predominated in number, four-year-olds - about $170 \mathrm{~mm}$, weighing more than $160 \mathrm{~g}$, which were found singularly. It is shown that the size-weight and ecological-biological characteristics of narrow-clawed crayfish, which make up the majority in biocenoses, are similar before regulation and after the formation of the reservoir.

The cultivation of the Australian red claw crayfish Cherax quadricarinatus (Von Martens, 1868) in warm waters in recirculating aquaculture systems could become an important element of aquaculture for the production of luxury gourmet products.

In the structure of aquaculture in the Middle Volga region development of aquabiotechnology makes it possible to use natural populations of crayfish for the tasks of creating crustacean farms and pasture aquaculture on the basis of Volga and Kama reservoir waters. The use of warm waters allows the year-round cultivation of new objects of industrial crayfish farming red claw crayfish. At the same time, natural ecosystems are not disturbed, and the rate of growth of marketable products under controlled production conditions allows not only to increase the volume of aquaculture products, but also to reduce the pressure of harvesting crayfish on natural ecosystems.

\section{References}

1. M.L. Kalaida, Ensuring water quality in the Republic of Tatarstan is a global civic duty of every modern person, The Earth Charter - a practical tool for solving fundamental problems of sustainable development: a collection of materials from the International Scientific and Practical Conference dedicated to the 15 th anniversary of the implementation of the Earth Charter principles in the Republic of Tatarstan, Kazan: Tatar. book publ. h., 148-152 (2016)

2. M.F. Khamitova, M.L. Kalaida, Study of changes in hydrobiological characteristics under conditions of local pollution in the Middle Volga region, LAP LAMBERT Academic Publishing, Omni Scriptum GmbH \& Co, KG, Saarbrücken, Germany, 310 (2018)

3. M.L. Kalaida, Objectives of the development of aquaculture in the Republic of Tatarstan at the present stage, Fish farming and fishery, 8 (139), 716 (2017) 
4. A.K. Bogeruk, I.A. Lukanova, World aquaculture: experience for Russia: scientific publication (M.: FSSI "Rosinformagrotech", 364, 2010) ISBN: 978-5-7367-0775-1

5. M.S. Stroykova, Observations on the biology of crayfish in the Tatrespublika, Proceedings of the Society of Naturalists at Kazan University, Kazan: KSU, LV (1-2), 171-180 (1937)

6. E.V. Kolmykov, Characteristics of long-toed crayfish of the Lower Volga, Int. region. meeting of astacologists, Astrakhan, 2-6 August 1999, Astrakhan: KaspNIRKH, 89-91 (2000)

7. A.V. Mirzoyan, R.P. Khodorevskaya, Biodiversity of objects of aquatic biological resources of the Volga-Caspian fishery basin, ASTU Bulletin., Ser.: Fishery, 4, 49-60 (2017) DOI: 10.24143/2073-5529-2017-4-49-60 ISSN: 20735529

8. V.I. Zhadin, The problem of reconstruction of the fauna of the Volga and the Caspian Sea in connection with the Volga hydro-construction, Tr. ZIN AS USSR, 7 (1), 28-36 (1941)

9. C.I. Ioffe, Substantiation and results of invertebrates acclimatization in large reservoirs of the Volga and Don, Acclimatization of fish and invertebrates in water bodies of the USSR (M.: Science, 148-155, 1968)

10. G. Mackeviciené, L. Mitskenene, V. Plyuraite, B. Joninene, Artificial reproduction of widefingered crayfish Astacus astacus L, Biotechnology for artificial reproduction of fish, crayfish and preservation of commercial fish stocks, Vilnius, 17 (2008)

11. S.Y. Brodsky, Astacidae of the reservoirs of the Kiliya Danube delta and some considerations on the origin of crayfish in reservoirs of the northwestern Black Sea region, Danube Limnological Research, Kiev, Naukova Dumka, 308-315 (1969)

12. E.N. Alexandrova, The main provisions of the strategy of reproduction of resources of Russian crayfish, Astacinae Latreille, 1802, ASTU Bulletin., Ser.: Fishery, 4, 9-21 (2017) DOI: 10.24143/2073-5529-2017-4-9-21 ISSN: 20735529

13. A.K. Aleksandrov, I.N. Zadoenko, N.Z. Stroganova, State of stocks, problems of protection and reproduction of crayfish in water bodies of Russia, Problems of protection, rational use and reproduction of crayfish (M.: Medinor, 614, 1997)

14. Charles Roquerlo, Un regain d'interet pour les ecrenissen, Adour - Garonne, 51, 13-17 (1991)

15. Y.M. Tsukerzis, Interspecies competition in closely related crayfish species, Astacus astacus L., A.leptodactylus Esch., Pacifastacus leniusculus Dana, Decapoda, Crustacea, DAN USSR, 229 (1), 250-252 (1976)
16. A.P. Demin, Water management complex of Russia: concept, state, problems, Water resources, 37 (5), 617-632 (2010)

17. C. Souty-Grosset, D.M. Holdich, P.Y. Noel, J.D. Reynolds, P. Haffner (eds.), Atlas of crayfish in Europe, Museum national d'Histoire naturelle, Paris, Patrimoines naturels, 64, 187 (2006)

18. A.V. Lukin, Results of using floodplain lakes for feeding carp in Tatrespublika, Proceedings of the Society of Naturalists at Kazan University, 55 (34), 55-68 (1938)

19. M.L. Kalaida, I.A. Bogatyrev, Crayfish in the reservoirs of the Republic of Tatarstan, International Scientific and Practical Conference: Water Power Energy Forum 2018 IOP Conf. Series: Earth and Environmental Science, 288, 012045 (2019) DOI: 10.1088/1755$1315 / 288 / 1 / 012045$

20. M.L. Kalaida, M.F. Khamitova, I.A. Bogatyrev, Features of the chemical composition of crayfish, Butlerov Communications, 57 (1), $72-79$ (2019)

21. Federal Agency for Fisheries [Electronic resource] (2020) Available at: http://fish.gov.ru/otraslevayadeyatelnost/akvakultura (accessed: 26.10.2020)

22. M.L. Kalaida, L.N. Sadykova, Prospects for growing Australian red claw crayfish Cherax quadricarinatus on warm waters of energy facilities, International Water and Energy Forum, 2018: collection of reports, in 2 vol., Kazan: Kazan. state energy un-ty, l, 237 (2018) 